\title{
The Genealogical Model of Savu, Eastern Indonesia
}

\section{Geneviève Duggan}

National University of Singapore, $2008^{1}$

\section{Introduction}

The Savu archipelago in the Indonesian province of Nusa Tenggara Timur (NTT) had little to offer in the past in terms of valuable goods like spices, resins, or precious wood (for example, sandalwood) and was bypassed by the traders. Largely overlooked by Portuguese and Dutch colonial powers that were active in the region, the people of Savu maintained their ancestral religion (Jingi Tiu) and traditional ways of life until recently when mass conversions to a world religion started in the 1970s. There has been little published research about the Savu people and their way of life except for the work of James Fox (1977; 1979) and Nico Kana (1978; 1983). Savu appeared to be an excellent field to research memory processes in a society that until recently had not written down its traditions.

Two analytical tools appeared to be useful in exploring memory processes and knowledge transmission. One is the concept of precedence as defined by Fox (1995); the second is a system of dualistic classification that continues to be used for many aspects of the society. In these matters, Savu shares common features with other Austronesian societies of the region. Following Edward Casey (2004) in classifying various aspects of memory, a distinction is made here between collective memory, which is public and to various degrees known by all members of the society,

1 The investigation of the genealogical model of Savu forms the main part of my $\mathrm{PhD}$ thesis, 'Processes of memory on the island of Savu', presented at the Sociology Department of NUS in 2008. 
and social memory, which is not necessarily public; on the contrary, it is often the insider knowledge of a small marginalised group.

After giving some general information about the geographical setting and the socio-historical background of the island, the paper deals with mechanisms of oral transmission of knowledge on Savu. It introduces key metaphors and examines processes in naming places, time and people. Emphasis is given to the role of genealogical knowledge in structuring the society. It is remarkable how people in Savu are able to remember long genealogies that have links at certain stages to the various parts of the island. ${ }^{2}$ Because it is well known that people remember what is important to them, meanings placed in such memories will be examined as well.

\section{Geographical Setting}

Savu, the main island of the archipelago of the same name, has 62,000 inhabitants and an area of 420 square kilometres. The small island of Raijua has a population of 6000 only. Savu gave its name also to the sea bordering Timor, Sumba, Flores and Solor. The dry season, which lasts six to nine months, is known as musim lapar, the hungry season, and people survive mainly by drinking the juice of the lontar palm tree, which can be kept in the form of syrup. This subsistence economy has been analysed by Fox in Harvest of the Palm (1977). Over the past ten to fifteen years, seaweed farming has developed along the west and southeast coasts, bringing a new source of revenue to those living near the beaches.

\section{Historical Background}

In pre-colonial times Savu had up to six independent politico-religious units or domains: Teriwu, Liae, Dimu, Menia, Seba and Mesara.

2 Of course non-verbal communication and practices are of importance in transmitting knowledge; they won't be dealt with here and are part of a forthcoming paper. 
However, Teriwu was absorbed by some of the other domains before colonial times but lived on as the oldest and most revered ritual centre. Menia was completely absorbed by Seba in the 19th century; it too retained its own religious organisation. By the end of colonial times, the island of Savu had four domains only: Seba, Mesara, Liae and Dimu, each having at least one independent Council of Priests for the ancestral religion, Jingi Tiu. In each domain a regent (raja) and a second regent (fetor) were chosen by the colonial power, creating new classes in the community. After Independence, the island was divided into two districts (kecamatan); East Savu comprising Liae and Dimu, and West Savu, comprising Seba, Mesara and the tiny island of Raijua. However, the previous domains continued to exist for ritual matters and in everyday speech people continued to refer to the traditional domains instead of the newly created districts. As a consequence of the autonomy law of the provinces (2001), Raijua formed its own district and for Savu five new districts were created, reflecting for the most part the structure of the ancient domains. In 2009, a new kabupaten, Savu-Raijua, was formed. Consequently, the investigation of Savu's past requires exploring all parts of the islands taking into account the existence of former domains where people have different practices and care to remember a divergent past. It is common knowledge that people keep in mind what is important to them.

\section{Social Organisation}

The society is classified as bilineal and recognises localised patrilineal descent groups $(u d u)$ and their lineages (kerogo) as well as two matrilineal descent lines or moieties (hubi) descended from two sisters. The moieties have formed subgroups (wini) over the course of time (Fox, 1972). A man should marry within the same wini, or at least within the same hubi as his mother (Kana, 1978). Consequently, the marriage rule from the moiety point of view is endogamy. From the patri-line position, it is of no relevance if the endogamy or exogamy rule is applied, and this differs from marriage rules of other societies in the region. Moreover there is no reciprocity in the gifts exchanged at 
marriage. Gifts flow from the bridegroom's family towards the bride's family which is at variance to practices of the area. Hubi and wini are highly relevant to the life crisis ceremonies, especially traditional baptism ( $\left.d^{\prime} a b^{\prime} a\right)$, marriage (kenoto) and funeral in which textiles play an important role (Duggan, 2001). Knowledge about patri- and matri-lines is kept in the genealogies, which can be traced over tens of generations to the founding female and male ancestors. A peculiarity of Savu is that genealogical knowledge is neither limited to male descent lines nor is it restricted to the ruling classes that emerged during colonial times. Genealogies are constant mnemonic devices used as stable references, and form the backbone of social and collective memories.

\section{Naming Processes}

Images and metaphors expressed in names are fundamental ways of remembering. Naming belongs to the set of classificatory practices and is an essential part of the cognitive apparatus of the mind. A constant image used in Savu is the botanical metaphor of a plant growing from the roots (kepue) or base ( $\left.d^{\prime} a^{\prime} i\right)$ to the tip (kolo) and encompasses the concept of precedence.

\section{Place-Names}

People relate to their landscapes cognitively and symbolically and develop mental maps (Basso, 1984). Place-names are not fortuitous; they recount in a condensed way a number of happenings on the island. For example, a place named Gurimonearu (literally 'eight dead men'), is reminiscent of warfare between the domains of Seba and Mesara. A place and its name become the proof, the witnesses, of an event in time. Place-names in a narrative help to visualise the situation, to anchor an event in a natural landscape. For remembering sites, a double encoding involving visual and auditory memory is at work. This process in creating mnemonic pegs activates different parts of the brain. 


\section{Naming Time}

Every domain in Savu has developed its own rules and terminology for naming time over a span of several years, from six (Dimu) to 49 years (Mesara). It has often been asserted that oral societies have neither calendars nor a sense of chronological, linear time. For keeping track of large chunks of time, each domain in Savu has developed its own range of physical mnemonic devices; some can be seen from far away (for example, the ridge of the house of the highest priest in Seba), others are kept in the house of a priest and are not seen by the population (for example, one leg of the sacrificed chicken is kept in the ritual house). Their remarkable variety points to a sense of creativity and a concern for accuracy when two devices are combined or are used in parallel. Here again a double encoding reinforces memorisation. For naming the immateriality of time, people in Savu have developed their own mechanisms that offer a framework for memory, fulfilling the purpose of calendars. They calculate their age, not by counting years, but by large ritual cycles (kelila ae).

Edmund Leach (1961) argues that in primitive societies, time process is not experienced as a succession of epochal durations, but either as an oscillation between opposites or as something discontinuous. As a consequence, the past lacks depth. In Savu, people's knowledge over tens of generations implies that they are able to consider the depth of their past. This is in contradiction to well established knowledge about traditional societies (Geertz, Leach, Misztal). Robert Barnes (1995), who has recorded a number of genealogies of the people of Kedang on the island of Lembata in the same province of NTT, argues that the people there consider time as a repetition resulting from irreversibility, thus combining the sense of cyclicity and linearity of time. People in Savu, too, are able to consider the passage of time, and thus its linearity and irreversibility despite the fact that they can use long cycles (up to 49 years) for structuring it. 


\section{Personal Names}

Personal names are meaningful and the sound of a name is of uttermost importance. Every individual has three to four categories of names: a personal name, a nickname, a technonym and a sacred and secret name, called a mantra name. The different names and forms of address a person has are evidence for his or her various identities, networks and roles in the society. Names often reflect social position where parallels have been made with the division of labour on a boat. This mnemonic device has been observed in other societies too (Manguin, 2000). Uli for example means 'rudder', also 'helmsman'. The personal names Uli and Gela ('mast') are often found in Savu male genealogies and correspond to the occupations that their ancestors had in the society. Names like Jawa and Hina ('foreign' or 'foreigner') indicate outside contacts, or possibly an adoption. Personal names are seldom found twice in the genealogies; this reduces confusion and lets the genealogies be more easily remembered. The choice of a personal name is of crucial importance because the rhythmic repetition of sounds, alliteration and assonances produced while reciting genealogies offer a structure for remembering. Rhythms have mnemonic properties (Rubin, 1995). Performances during which genealogies are recited, stress the cohesion of the group during a gathering. They require high concentration from the speaker and extreme attention from the silent audience.

At funerals, the paternal and maternal genealogies of the deceased are recited. Referring to the image of a growing plant, the expression is huhu kebie ti d'a'i ta d'ida, or piling up beams from the base to the tip, thus connecting the deceased to the world of his or her maternal ancestors. The recitation of genealogies can be understood better by using another metaphor; it is as if reciting genealogies symbolically corresponds to the building of the edifice Savu. The image of piled beams from the base to the apex reveals an essential mental structure for the genealogical knowledge in Savu. 


\section{Mantra Names}

Everybody has a sacred and secret name, or mantra name, throughout their life. It is created by a close kin at birth and it can evolve over their lifetime. Marriage is the occasion for a bride and bridegroom to hear each others mantra name, which is not disclosed to those attending the ceremony. At death, the mantra name is revealed to a large social group and becomes part of the apparatus for remembering Savu's history. Some verses of the mantra name might be incorporated in chants uttered at public gatherings.

\section{Essential Links}

In the same way that personal names help position people in the social structure, place-names help to locate them in their environment, which possesses distinctive features. Anarrative helps to transmit and memorise the names of people and their group of origin ( $u d u$ or hubi/wini), because the genealogy of the narrator and his or her link to protagonists in a story is usually given either at the beginning or the end of the narrative. The narrative exemplifies people's traits and a groups' attributes. It is not a matter of whether these stories are true or constructed; this is how Savu people see and remember them. Those are facts used for building the genealogical 'scaffolding' in all domains. People are concerned to have a coherent structure that is reasserted at different stages of their history so that they are all one people, always connected.

At times of warfare and territorial conquest, alliances and names of participants are kept in mind. The helpers of the conqueror are remembered in association with the acquisition of plots or parcels of land (rai kowu muhu). It allows also for horizontal links between domains and for an epoch to be marked in the genealogies. Individual histories supersede history in social memory. However, different versions of an event do not alter the value of personal narratives. People in Savu remember through names, but also through the absence of names and the absence of rituals. Blanks and silences are also mnemonic devices. 


\section{The Genealogical Model}

\section{An Architectural Mind}

Metaphors like huhu kebie, 'to pile the beams', and ti d'a'i ta d'ida, 'from the base to the tip', are essential for understanding how people in Savu think about their society. In this architectural comparison, a beam or log corresponds to one generation and subsequent superimpositions form a building. Thus, when reciting genealogies people construct (or reconstruct) the edifice Savu. However, the ability to remember long genealogies does not seem an extraordinary performance for an Austronesian society that has oral traditions only. Fox in Roti and Barnes in Kedang have already recorded genealogies with over 20 or more generations. Up to the present, no genealogies of the length of those I had access to in Savu, remembered with their segmentations and cognate lines, have been recorded yet from that area. In Savu, everybody has a genealogy. This is the case in Roti too although there it is the nobility only that owns extended genealogies; the common people derive their genealogies from one of the dynastic lines. This is not the case in Savu. When counting all descendants of rulers since Portuguese times, most of the people can make a link to a former ruler either through their father or their mother. However, they do not make a dynastic claim and do not think of themselves in that way. Savunese regard themselves in a more egalitarian relationship as one people of the same origin whose ethnic identity is defined through a common ancestor, and whose territory extends to the natural borders of their island.

\section{Extension of the Genealogical Model}

The genealogical model is not applied exclusively to people, but also to the places occupied successively by their ancestors. The path taken by the ancestors to arrive at their present day settlements is remembered through a combination of a succession of ancestor names and places or topogenies (Fox 1997). In Savu, people remember the places where their ancestors have lived since the beginning of their history and their journey on the island. Besides genealogies of people and topogenies, 
people have, in the domain of Dimu and Mesara, named houses that have genealogies too, thus creating 'domogenies'. Where a clan ( $u d u)$ did not form lineages (kerogo), the branching groups are referred to as the founding house (èmu kepue) of a new settlement. The ritual meat shared by the group is kept in a basket called kerogo. Despite the fact that in different parts of the island people choose either to name an ancestral house or to name a lineage, they all have a mental representation of the topogenies and consequently of the chronology of the ancestral houses. It is remarkable how Savu's 'memoryscape' is structured in the form of genealogies.

Two main ideas derive from the memorisation of the path of the ancestors and of the genealogies of places and houses. One is that of shared origin and the second is that of an order of precedence as a fundamental organising principle, connecting the past and the present. The idea of a common origin is recurrent in the area (Fox; Reuter; McWilliam). This concept implies that newcomers are either treated as descendants of Savu people who returned to the island, or they have been incorporated and their genealogies constructed to fit the general pattern so that it is no longer possible to trace them as newcomers or outsiders, except through their mantra name.

In many societies genealogies validate relations between groups and it is the case in Savu too. According to Vansina, genealogies can be manipulated whenever needed. However, if the knowledge about genealogies is not the prerogative of trained specialists of the ruler's entourage, but is shared by a number of people, it is not easy for someone to change their origin. One cannot re-arrange one's genealogy so easily when the knowledge is not the prerogative of a few professionals. This would only be achievable through consensus among all the people on the island, and then with the agreement of the priests (and possibly of the ruler too). Powerful groups have tried to re-arrange the genealogies of certain clans. Nevertheless some subgroups could not be silenced, resulting in today's controversy among clans whose domain has been absorbed by other groups. The attempt to impose an official version of the past for the island's collective memory failed; the counter- 
memory of certain groups could not be contained. 'The struggle against power' Milan Kundera aptly remarks 'is the struggle against forgetting' (1980).

One reason for remembering long genealogies is certainly the fact that they connect a member of the community with his or her ancestors so that there is no gap between mythical times and the present. The deceased are sent to the world of their ancestors following the genealogical path. A second reason for remembering genealogies is certainly to support the claim of land ownership. Land can be acquired through participation in warfare. A narrative accompanied by the recitation of the genealogy of the protagonists and their allies validates the gift of the land.

The female genealogies are important for the same reasons. They are as much the backbone of the socio-historical past of Savu as the male genealogies because a deceased person enters the world of their ancestors of their maternal line. Female genealogies too are related to land ownership because a father or a brother could give some land to his daughter(s) or sister(s) that then could be inherited from mother to daughters until the extinction of the female line, in which case the land has to be given back to the descendants of the ancestor who made the gift in the first place. This is a right to usufruct, not a proper land ownership. This custom is known under different names on various parts of the island. One is rai lere, which means literally 'land that follows one another', thus from generation to generation in the progenitrix line. The second type of land, rai hèru kebèla, is surrounded by more sacredness. Hèru means spindle and kebèla (bèla, large) might be the contraction of kepepe bèla, which is the female heirloom basket containing ceremonial weavings. Thus the expression refers to female heirloom land. The moieties (hubi) and their subgroups (wini) own specific woven patterns as identification markers of their group. They also have kept in mind the chronological order of the creation of these ikat motifs displayed on their tubular cloths as a way to remember the history of their maternal lines. This is visually remembered through the position of the weavings in the heirloom basket. The genealogical model that is applied to textile patterns reveals once more an essential 
cognitive process for remembering in Savu. The knowledge about narratives, female genealogies, as well as of the chronology of patterns (or 'textilogeny') is crucial for the claims of the female groups to the use of their heirloom land.

\section{Conclusion}

Everything has a meaning and a place in Savu society. The expression, huhu kebie, which refers to the genealogical knowledge, articulates Savunese thought in the matter of chronological, linear time. Two recurring concepts have been developed as efficient mnemonic devices to assist in the preservation of oral memories. Together they shape what I would call a distinctive 'economy of knowledge' in Savu. They are the metaphor of a growing plant, in combination with the mental image of the structure of a building as a way of thinking about genealogies. These two cognitive models are applied in such a number of varied situations that they are a matrix for memory processes. Without a doubt the mapping of the most relevant elements in the society is either in the form of a growing plant or in the model of genealogies, from the migratory path of the ancestors ('topogenies'), to the places and houses they occupied successively ('domogenies') and the weavings they created one after another ('textilogenies'). This conveys not only a sense of chronology but of history because a chronological order of events in the past is the primary characteristic of history (Vansina, 1985). In this society, the image of the genealogy itself, with its ordered succession of generations over time, has been extended in a unique way to apply not only to people but to a number of other important heritable aspects of material culture.

Genealogies in oral societies were believed unreliable until Fox published the dynastic genealogies of Roti and provided the historical evidence to corroborate them (1971). When comparing the knowledge contained in Vereenigde Oostindische Compagnie (VOC) documents since the mid-17th century with what collective memory in Savu knows of the time, the names in written records could be found in the 
genealogies with very few exceptions. The documents corroborate the genealogical knowledge transmitted orally only. However, colonial and indigenous sources reveal a different emphasis on events. The colonial power found little worth recording in what was happening on the island, except in cases of misconduct, murder and rebellions. Historians would be left with a very partial view and limited information about this society were they to rely only on written sources for writing about Savu's past. Social memory is much richer than the information that has been kept in written texts about Savu.

The overall coherence in the male and female genealogies is a clear response to the supposed limited memory capacity in oral cultures or among illiterate people (Misztal; Cubitt). Yet the paradox is that because of contact with modern religions and literate societies, the precious ancestral knowledge of Savu is disappearing; the rising generations are not interested in learning the ancestral knowledge, which is disregarded by local literate people. Some Savunese now learn the genealogies in the New Testament Gospels instead of their own. The paradox is that it is those who have been educated who have the most profound disregard for the ancestral, oral knowledge that is essentially kept now by followers of the Jingi Tiu religion. Common people are as much the agents in historical processes as the ruling and literate classes. This is why Eric Wolf stated that "we need to uncover the history of the people without history" ([1968] 1982). For centuries historians considered written records only, glorifying the deeds of rulers and the elites for whom they worked while disregarding the bulk of knowledge transmitted orally in lower classes and among minority groups. This is one of the reasons why archaeology has repeatedly proven historical events derived from written records to be wrong. After neglecting oral records for centuries historians in literate societies are now paying attention to the 'historyfrom-below'. Savu society while becoming literate should learn from previous experience and not neglect the small voices of its history (Ranajit Guha, 1996).

The investigation of oral traditions and of the genealogical model in Savu shows that anthropology offers reliable ways to study the history 
of an oral society if taking in account all its social groups. Otherwise the history of societies with non-written traditions will suffer the same weaknesses as those of literate societies. The capacity of the Savu people for remembering very long genealogies is indeed astounding; it is a fact, and the way they structure knowledge and connect data using the genealogical model, is certainly part of the explanation.

\section{References}

\section{Books and Journals}

Barnes, Robert.H.(1995). 'Time and the Sense of History in an Indonesian Community: Oral Tradition in a Recently Literate Culture'. In Diane Owen Hughes and Thomas R Trautman (eds). Time; histories and ethnologies. Ann Arbor: UMI Press.

Basso, Keith H (1984). 'Stalking with Stories: Names, Places, and Moral Narratives among the Western Apache'. In E Bruner (ed.) Text, play and story. Washington DC: American Ethnological Society.

(1996). 'Wisdom sits in Places'. In Steven Feld and Keith Basso (eds). Senses of Place. Santa Fe: School of American Research Press: 53-90.

Bloch, Maurice (1998). How we Think they Think: Anthropological Approaches to Cognition, Memory, and Literacy. Boulder: Westview.

Casey, Edward (2004). 'Public Memory in Place and Time'. In Kendall R Phillips. Framing Public Memory. Tuscaloosa: University of Alabama Press.

Connerton, Paul [1989] (1998). How Societies Remember. Cambridge: Cambridge University Press.

Cubitt, Geoffrey (2007). History and Memory. Manchester: Manchester University Press.

Detaq, Yakob (1973). Memperkenalkan Kebudayaan Suku Bangsa Sabu. Ende: Nusa Indah.

Duggan, Geneviève (2001). Ikats of Savu; Women Weaving History in Eastern Indonesia. Bangkok: White Lotus.

(2004a). 'Woven Blossoms, Seeds of History'. In Hali. London:

Centaur publications. (134) 110-114.

.2004b. Woven Traditions, Collectors and Tourists: a Field Report

from Savu. In Fiona Kerlogue (ed). Performing Objects; Museums, Material

Culture and Performance in Southeast Asia. London: Horniman : 103-118.

Fox, James J (1971). 'A Rotinese Dynastic Genealogy: Structure and Event'. In The

Translation of Culture: Festschrift for Evans-Pritchard. London: Tavistock Publications.

(1977). The Harvest of the Palm: Ecological Change in Eastern Indonesia.

Cambridge: Harvard University Press. 
(1979). 'The Ceremonial System of Savu'. In AL Becker and AA Yengoyan (eds), The Imagination of Reality: Essays on Southeast Asian Coherence Systems. Norwood: Ablex Publishing Corporation : 145-173.

(1980). 'Models and Metaphors: Comparative Research in Eastern Indonesia'. In J Fox (ed.), The flow of Life: Essays on Eastern Indonesia. Cambridge: Harvard University Press: $327-333$.

(1995). Origin Structures and Systems of Reference in the Comparative Study of Austronesian Societies. Austronesian Studies. August 1995. Canberra: RSPAS, ANU: 27-57.

(1996). The Transformation of Progenitor Lines of Origin: Pattern of Precedence in Eastern Indonesia. In J Fox and C Sather (eds), Origins, Ancestry and Alliance. Explorations in Austronesian Ethnography. Canberra. RSPAS, ANU: $130-146$.

(1997) (ed.). The Poetic Power of Places. Comparative Perspectives on Austronesian Ideas of Locality. Canberra. RSPAS, ANU.

Geertz, Clifford. [1973] (2000). The Interpretation of Cultures. New York: Basic Books.

Guha, Ranajit (1996). The Small Voice of History. In Shahid Amin \& Dipesh Chakrabarty Subaltern Studies IX: Writings on South Asian History and Society. Dehli: Oxford University Press.

Kana, Nico L (1978). Dunia orang Sabu. Unpublished thesis, Universitas Indonesia di Jakarta. Jakarta: Ford Foundation.

(1980). The Order and Significance of the Savunese House. In J Fox (ed.), The Flow of Life: Essays on Eastern Indonesia. Cambridge: Harvard University Press: 221-230.

(1983). Dunia orang Sabu. Jakarta: Sinar Harapan.

Kundera, Milan (1980). The Book of Laughter and Forgetting. New York: King Penguin

Leach, Edmund (1961). Rethinking Anthropology. London: Athlone Press.

Lewis, E D (1988). People of the Source: the Social and Ceremonial Order of Tana Wai Brama on Flores. Verhandlingen van het Koninklijk Instituut voor Taal-, Land-, en Volkenkunde, No. 135. Dordrecht; Foris Publications.

(1996). Origin Structures and Precedence in the Social Orders of Tana'Ai and Sikka. In JJ Fox and C Sather (eds).(1996), Origin, ancestry and alliance. Explorations in Austronesian ethnography. Canberra: RSPAS, ANU: 154-174.

Manguin, Pierre-Yves. (2000). Shipshape Societies; Boat Symbolism and Political systems in Insular Southeast Asia. In Techniques et Culture. Paris: Maison des Sciences de l'Homme 35-36: 373-400.

McWilliams, Andrew (2002). Paths of Origin, Gates of Life. A Study of Place and Precedence in Southwest Timor. Leiden; KITLV.

Misztal, Barbara (2003). Theories of Social Remembering. Maidenhead: Open University Press.

Rubin, David (1995). Memory in Oral Traditions. The Cognitive Psychology of Epic, Ballads, and Counting-out Rhymes. Oxford: Oxford University Press. 
Reuter, Thomas (2002a). The House of Our Ancestors. Leiden: KITLV.

(2002b). Custodians of the Sacred Mountains; Culture and Society in the Highlands of Bali. Honolulu: University of Hawaii Press.

Vansina, Jan (1985). Oral Tradition as History. Madison: University of Wisconsin.

Wolf, Eric [1968] (1982). Europe and the People without History. Berkley: University of California Press. 